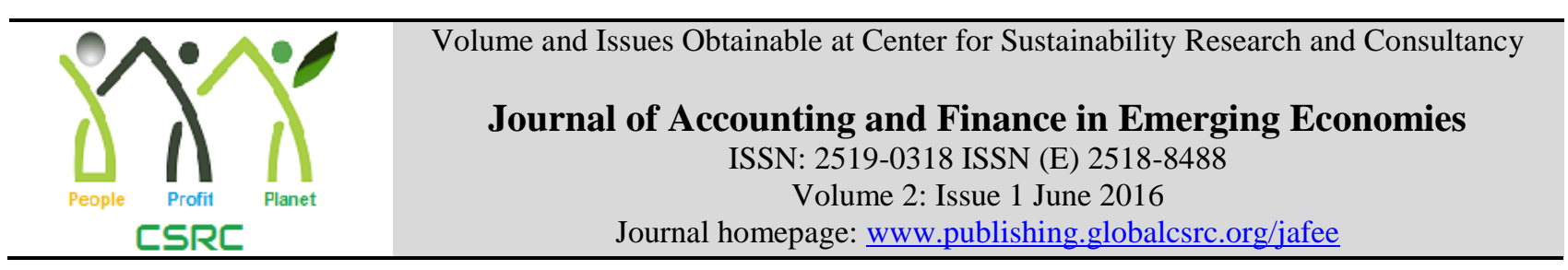

\title{
Financial Analysts' Processing of Financial Reporting Information in Emerging and Frontier Markets
}

\author{
${ }^{1}$ Philip Jehu, ${ }^{2}$ Mohammad Azhar Ibrahim
}

${ }^{1}$ PhD Scholar, TISSA-UUM School of Accountancy, University Utara Malaysia, jehuphilip@gmail.com ${ }^{2}$ Senior Lecturer, TISSA-UUM School of Accountancy, University Utara Malaysia, m.azhar@uum.edu.my

\begin{tabular}{lc}
\hline ARTICLE DETAILS \\
\hline History & \\
Revised format & May 2016 \\
Available Online & June 2016
\end{tabular}

Keywords

Financial analysts

Information processing

Incentives

Emerging markets

Frontier markets

JEL Classification:

G17, L86, L89

\begin{abstract}
Objective: The purpose is to establish the relationship between the analysts' stock valuation, the reporting environment and the stock recommendations. And to investigate the process of incorporating both quantitative and qualitative information into their forecasts.

Methodology: The research will be archival, obtaining historical information from DataStream, Stock Exchanges and MSCI. A survey will also be carried out to corroborate findings, as the analysts' valuation process may not be obtained through desk research.

Results: The results are expected to show evidence for the incentive conflicts of the analysts' decisions with regards to the peculiarities of the macroeconomic environments under consideration.

Implication: The write up has implications for sell-side analysts where they have perceived incentive conflicts when they make recommendations. The research contributes to the argument on the conflicts of interest analysts face in forecasting earnings and making recommendations within the markets peculiar environment.
\end{abstract}

(C) 2016 The authors, under a Creative Commons AttributionNonCommercial 4.0

Corresponding author's email address: jehuphilip@gmail.com

Recommended citation: Jehu, P. and Ibrahim, M. A., (2016). Financial Analysts' Processing of Financial Reporting Information in Emerging and Frontier Markets. Journal of Accounting and Finance in Emerging Economies, 2 (1) 39-46. DOI: https://doi.org/10.26710/jafee.v2i1.72

\section{Introduction}

Financial analysts play a very important role in generating, processing and disseminating corporate financial information to investors. Their activities include among others; corporate data collection, forecasts earnings, stock valuation and stock recommendations. However, studies have shown that financial analysts are imperfect intermediaries, in part because of incentive conflicts with biased earnings forecast reports and recommendations (Beyer, Cohen, Lys, \& Walther, 2010; Healy \& Palepu, 2001). Friesen and Weller (2006) attempted to quantify the analyst' biases in earnings forecasts. Their model present evidence of analysts' overconfidence on the accuracy of their own information. They show that these biases exist, in their data. 
These conflicts of interest within the context of the analysts' market environment tend to influence their decisions.

The analyst' decision does not hinge solely on the valuation of forecast earnings. The process begins with incorporating all publicly known information both quantitative and qualitative as contained in the company's accounts and reports such as economic and industry outlook, quality of management, business connections, competitive advantage, strategies, and financial indices. It is on this basis that analysts make their decisions. Since their decisions to public disclosure are not regulated, analysts tend to have conflicts of interest. It is pertinent to note that financial analysts as economic agents have their own incentives, similar to managers of companies. These incentives can affect the relevance and reliability of information that investors acquire from the analysts. In addition, research has shown that analysts' bias recommendations will diminish with the establishment of financial regulation (Barniv, Hope, Myring, \& Thomas, 2009; Chen \& Chen, 2009).

Some academic research have been conducted on financial analysts' activities in the capital markets, with focus on developed markets. Analysts in these markets perused, and based their conclusions on quantitative earnings forecast (Lustgarten \& Tang, 2008; Mest \& Plummer, 2000; Stickel, 1990; Wong \& Zhang, 2014), financial regulations (Bradshaw, 2009), the All Share Index and market capitalisation (Boissin \& Sentis, 2012; Karamanou, 2012). Sufficient attention has not been given to the financial analysts' information processing role in the emerging and frontier markets. This is evident with the studies carried out (e.g. Corredor, Ferrer, \& Santamaria, 2014; Jegadeesh \& Kim, 2006) in G7 countries and European countries respectively. But the increase in financial deregulations, globalisation of capital markets, cross-border listings, economic growth and Foreign Direct Investments (FDI) around the world, underscores the need to also study the emerging and frontier markets is. Also, Bradshaw (2009) asserts that researchers are keenly interested in the valuation process that leads to stock recommendations, but which unfortunately is not easily penetrated using empirical archival research, especially from financial reports.

In recent years, the concern for transparent and credible financial reporting as a necessary means designed to enhance information flow and resource allocation in the capital markets cannot be over emphasized. An important goal of financial reporting is to bridge the gap between and among the market participants. However, financial accounting and reporting itself does not completely resolve this information problem. The information asymmetry that exists between company managers and investors (shareholders) makes equity analysts' financial intermediation necessary. In their study, Brennan, Jegadeesh, and Swaminathan (1993) found that firms followed by many financial analysts tend to lead those with fewer financial analysts in responding to new market information. This was consistent with the findings of Chuang and Lee (2011) that firms followed by fewer analysts tend to react to marketwide information more sluggishly than firms followed by more analysts.

Of recent, financial scandals and capital market crashes around the world shows the necessity for corporate financial transparency in order to regain investors' trust. Companies that fail to communicate clearly to investors are likely to face difficulty in raising more finance. The professional analyst is expected to be fair in interpreting and communicating the necessary information to the investors objectively without prejudice. However, financial analysts face incentive conflicts sometimes leading to bias reports and stock recommendations. This poses concern as to whether reliance could be placed on the accounting valuation process that led to such reports. The research aims to assess the importance of financial analyst as information intermediary in the equity market. The main purpose is to establish the relationship between analysts' valuation, earnings forecast and stock recommendations. To achieve this, the study investigates the nature of the disaggregated information that is most important to analysts in their earnings forecast. It explores the regulatory and institutional factors that account for the differences in analysts' role and their forecast properties across markets. The study also examines how financial 
analysts' incentive conflict affect the reliability and relevance of information they supply to investors and to establish whether analysts rely on accounting-based valuations models in making earnings forecasts and recommendations.

Prior studies in this area focused mainly on the developed markets. With global financial contagion around the world, emerging and frontier markets peculiarity sometimes viewed as investors haven becomes of interest. This research has potential to contribute knowledge and to build on previous studies. For example, Karamanou (2012) suggested that future research should examine the link between the financial analysts and other market variables, in both emerging and the frontier markets. However, the study will go further to examine analysts' role in the frontier markets. The research will also contribute by extending the models, methods and analysis tools that were used in previous studies.

Credible and transparent financial reporting is essential for efficient resource allocation in the capital markets. Financial reporting should reduce the information asymmetry that exist between managers and outside stakeholders. The financial analysts do not only play a complementary intermediation role to reduce this information gap, but expected to exhibit independence and objectivity devoid of incentive conflicts in their reports and recommendations. The recent global financial crisis reflects the relevance of an efficient capital markets and the important consequences that market frictions could have on the society. The series of financial reporting scandals around the world has major consequences for company employees - jobs and pensions, and financial markets. It is equally significant not to quickly forget the events which led to introduction of International Financial Reporting Standards (IFRS). These events further highlight the necessity for high quality financial intermediation. Financial analysts are important intermediaries that are generally expected to have superior information processing skills. However, because financial analysts tend to have incentives to provide inaccurate and bias information to outsiders in order to impress company management, it is still arguable whether analysts actually add value to the society.

The paper follows with literature review in section 2 , followed by the proposed method in section 3 . The write up finishes with a conclusion.

\section{Literature review}

\subsection{Conceptual framework}

\subsubsection{Stock recommendations}

Stock recommendations represents analysts' opinion to investors whether to buy, sell or hold a given stock. They are the main information source for equity investors based on their stock coverage. The recommendations are associated with significant reactions in stock prices, and the macroeconomic conditions. As market intermediaries, the analysts collect, examine, analyse and divulge valuable advice to investors. Such advice compares the present and expected market valuation of a given stock which translate into recommendation. In their study, Kliger and Kudryavtsev (2013) found that positive (negative) excess returns which follows recommendation upgrades (downgrades) are stronger when accompanied by daily volatility index decreases (increases). These behavioural pattern of the analysts is most likely not going to yield itself to investors track.

Empirical findings show that financial analysts play important role in the capital markets. Healy and Palepu (2001) asserted that financial analysts in the capital market play a valuable role in improving market efficiency. They depend on information they collect whether from private or public source, and 
on that basis evaluate companies' performance. They then make earnings forecast and give recommendations to investors. This is evidence that analysts add value to the capital markets.

\subsubsection{Financial analysts' decision process}

Analysts' research bridges the information asymmetry and aid prices reflect information on security's fundamentals. Their private incentives however, potentially contribute to misguided findings, with possible market fixation on such optimism of misleading reports. Farooq (2013) argued that lack of proper disclosure makes it difficult for analysts to gauge firms' true value. Consequently, they rely on private information source about firm in order to make informative predictions as well as recommendations.

According to Bradshaw (2009), researchers are keenly interested in the valuation process that leads to stock recommendations, but which unfortunately is not easily penetrated using empirical archival research. The study found a strong evidence that the analysts' personal conflicts of interest has less impact on the association between their forecasts and stock recommendations. In their survey on analysts' decision processes, Ramnath, Rock, and Shane (2008) pointed out that analysts' earnings forecasts depend mostly on disaggregated and qualitative information. The two most frequently used sources of information, other than reported earnings are management communication and segment reporting.

\subsubsection{Human information processing}

There has been increasing interest in behavioural decision making or human information processing. In their study, Libby and Lewis (1982) examined some research that exposes humans as poor intuitive statisticians. They asserted that this has subsequently accelerated the application of statistical sampling and regression analysis in auditing, and other decision aids developed to overcome common heuristics. They evaluated accounting research conducted using the lens model, predecisional behaviour, probabilistic judgment, and cognitive style approaches. This behavioural intuition in human is argued to play a significant role on the final outcome of the process.

\subsubsection{Analysts' incentive conflicts}

According to Healy and Palepu (2001) although there is evidence that financial analysts produce valuable new information through their earnings forecasts reports and stock recommendations, there are yet systematic biases in financial analysts' outputs, seemingly arising from the incentive conflict that they face. This was buttress by Dechow, Hutton and Sloan (2000) that analysts do have incentives in making positive forecasts and recommendations when their brokerage firm is hired to underwrite a new securities issue. Information asymmetry and incentive conflicts impede efficient resource allocation in a capital market economy. The institutions that are established to facilitate credibility in disclosure requirement by managers play important role in mitigating the problems. Analysts forecasting research has evolved considerably since the early work documenting what appeared to be a bias toward optimism in forecasts and recommendations (Ramnath et al., 2008). Ramnath et al., (2008) stressed that "incentives related to the career concerns of analysts, the underwriting and trading incentives of their employers, and how the incentives of, and communication with the company management influence analyst behaviour." Francis (1997) identified three types of bias that could affect analysts' forecasts optimism: First is selection bias where analysts report and recommend only favourable views about stock performance but keep silent when it is unfavourable. The second is reporting bias where analysts deliberately report some positive amount in order to foster their relationship with management and to generate brokerage. The last is cognitive bias, where analysts inadequately process the available information. This incentive conflict ultimately influences the analyst's decision. 


\subsubsection{Valuation models}

Research findings by Barth and Hutton (2004) indicates that whereas analysts incorporate information identifying firms with low persistent accrual, on revised results into their earnings forecast, investors however do not incorporate this information into their valuation assessment. In another study, Ramnath et al., (2008) asserted that it is a herculean task to discover the valuation model and important information that determines equity stock prices. However, in an efficient market analyst forecasts will immediately reflect all disclosed information. De Franco, Vasvari and Wittenberg-Moerman (2009) stated that the bond market is of higher sophistication level relative to the equity market. The presence of rating agencies provides independent and objective information which aid to determine prices of fixed income securities. This suggests bond analysts will add less bias to their reports and recommendations than do equity analysts.

Demirakos, Strong, and Walker, (2010) investigated the choice of valuation model by equity investment analysts to know whether the model affects the accuracy of their target prices forecast. In their findings, the Discounted Cash Flow (DCF) models outperformed Price-Earnings (PE) models. Consistent with this findings, Imam, Barker, and Clubb (2008) examined the valuation models used by investment analysts in the UK. They observed that:

"Analysts perceive the DCF which is somewhat sophisticated, to be significantly more important than prior survey evidence suggests, although we also find the continued importance of 'unsophisticated' valuation multiples, notably the price/earnings ratio" (p.503).

They found that, even though the DCF model is ostensibly credible, it is rarely relied upon in determining target prices and investment recommendations. It requires an understanding of the socioeconomic context and motivations in addition to the valuation models.

Earnings forecasts which are futuristic tend to be more accurate than the historical time-series earnings models. This is likely because they incorporate company news immediately into their forecasts than time-series earnings models. The question now is, what are the valuation models equity analysts employ in the emerging and frontier markets?

\subsubsection{Agency problem}

According to Beyer et al., (2010) "the corporate information environment evolves endogenously as a result of information asymmetries and agency problems between managers, entrepreneurs, and investors" (p.296). They concluded that, "to date, little is known about the association between firms' mandatory disclosure requirements, voluntary disclosure policies, and the information produced by equity analysts" (Beyer et al., 2010, p. 335). In another study, Armstrong, Guay and Weber (2010) reviewed the role of transparency in financial reporting and how it reduces governance-related agency conflicts among the stakeholders. The financial analysts also as economic agents face this agency conflict especially when their firms act as underwriters to their client.

\subsubsection{Analysts' information environment}

According to Yin and Zhang (2014) little is documented in the literatures concerning the financial analysts' environment and its effect on their decision. Beyer et al. (2010) reviewed the decisions that influence corporate information environment in the stock markets as: mandatory regulatory disclosure, voluntary disclosure and analysts reporting decisions. Other current macroeconomic news and variables and analysts' professional expertise are areas of influence to their decisions.

\subsection{Theoretical framework}

Ball and Brown (1968) concluded that the income number of a firm for a given year captures a half or more of all the information made available for that year. This statement has implication for the efficient- 
market hypothesis. They also observed that the process of measuring the value of information about income and its statistical nature is little understood. This process of assumed value of the qualitative information that forms part of the analysts forecast basis is of keen interest.

The financial analysts' intermediation role is expected to complement in reducing the information asymmetry which ultimately reflects on stock prices. The agency theory comes to relevance in this aspect. Also, the analysts sometime act as both agent of the management as well as that of the investor. According to Bradshaw (2009) the analyst's information processing role on which he forecast earnings and generate stock recommendations is of implicit interest. These variables need to be explored within the information environment of both the emerging and frontier markets.

The information environment could be facing differing characteristics of regulations. Bradshaw (2009) supported the fact that when analysts' activities are regulated, there would be positive effect on the decision usefulness of their recommendations. Where there are several overlapping regulations, it would be uncertain whether which specific regulation at a point limits the analysts' conflict of interest. In the emerging and frontier markets, regulations might be influenced by infrastructural and macroeconomic conditions. Consistent with the findings of Barniv et al. (2009) and Chen and Chen (2009), tighter regulatory changes alters the characteristics of analysts' activities, and can be observed before and after the regulations were introduced.

\section{Method}

The research methodology will be both archival and survey study, that is, historical data will be obtained from I/B/E/S earnings forecast through DataStream, MSCI Index, and Stock Exchanges, on which statistical analysis will be carried out using Stata application. A survey of financial analysts' valuation process that lead to their stock recommendation will be carried out. The study covers the emerging and frontier equity markets as extension from previous research on the developed markets. Data source from previous research such as I/B/E/S, MSCI, and DataStream will be explored in order to benchmark the research outcome with that of the developed economies. Data will be collected for two countries; one in the emerging market, the other from the frontier market. Non-probability purposive sampling of financial analysts, stockbrokers and investment advisors. We shall use DataStream to obtain analysts earning forecast reports from $\mathrm{I} / \mathrm{B} / \mathrm{E} / \mathrm{S}$ database. The panel data will be analysed using Stata statistical analysis application. The extent to which findings could be generalized to all emerging and frontier market countries around the world is limited to the countries under study, as they may not be a sufficient representation of the whole markets. The research is also subject to all the limitations recognized in data collection.

\section{Conclusion}

In conclusion, the study seeks to investigate the nature of the disaggregated information and valuation process the analysts use to make recommendations. It aims to establish the link between these four variables, namely; analyst's earnings forecast, reporting environment, valuation incentives and stock recommendations. Prior works indicate that valuation multiples such as DCF and PE models were used by analyst as basis of their decisions (Demirakos et al., 2010; Imam et al., 2008). But less sufficient evidence on the impact of the analysts reporting environment has been documented (Yin \& Zhang, 2014). Therefore, the research will contribute to the debate on analyst's bias in forecasting earnings and the incentives of making a particular recommendation within the context of the reporting environment. Although the analyst's incentives are not easily verified through archival means, survey will however be carried out in order to determine the extent bias. 


\section{References}

Armstrong, C. S., Guay, W. R., \& Weber, J. P. (2010). The role of information and financial reporting in corporate governance and debt contracting. Journal of Accounting and Economics, 50(2-3), 179 234. http://doi.org/10.1016/j.jacceco.2010.10.001

Ball, R., \& Brown, P. (1968). An Empirical Evaluation of Accounting Income Numbers. Journal of Accounting Research, 6(2), 159-178. http://doi.org/10.2307/2490232

Barniv, R., Hope, O., Myring, M. J., \& Thomas, W. B. (2009). Effects of Recent Regulations, 84(4), 1015-1039.

Barth, M. E., \& Hutton, A. P. (2004). Analyst earnings forecast revisions and the pricing of accruals. Review of Accounting Studies, 9(1), 59-96. http://doi.org/10.1023/B:RAST.0000013629.59222.df

Beyer, A., Cohen, D. a., Lys, T. Z., \& Walther, B. R. (2010). The financial reporting environment: Review of the recent literature. Journal of Accounting and Economics, 50(2-3), 296-343. http://doi.org/10.1016/j.jacceco.2010.10.003

Boissin, R., \& Sentis, P. (2012). Long-run performance of IPOs and the role of financial analysts: some French evidence. The European Journal of Finance, 20(2), 125-149. http://doi.org/10.1080/1351847X.2012.689773

Bradshaw, M. T. (2009). Analyst information processing, financial regulation, and academic research. Accounting Review, 84(4), 1073-1083. http://doi.org/10.2308/accr.2009.84.4.1073

Brennan, M. J., Jegadeesh, N., \& Swaminathan, B. (1993). Investment analysis and the adjustment of stock prices to common information. Review of Financial Studies, 6(4), 799-824. http://doi.org/10.1093/rfs/6.4.799

Chen, C. Y., \& Chen, P. F. (2009). NASD rule 2711 and changes in analysts' independence in making stock recommendations. Accounting Review, 84(4), 1041-1071. http://doi.org/10.2308/accr.2009.84.4.1041

Chuang, W. I., \& Lee, B. S. (2011). The informational role of institutional investors and financial analysts in the market. Journal of Financial Markets, 14(3), 465-493. http://doi.org/10.1016/j.finmar.2010.12.001

Corredor, P., Ferrer, E., \& Santamaria, R. (2014). Is cognitive bias really present in analyst forecasts? The role of investor sentiment. International Business Review, 23(4), 824-837. http://doi.org/10.1016/j.ibusrev.2014.01.001

De Franco, G., Vasvari, F. P., \& Wittenberg-Moerman, R. (2009). The informational role of Bond analysts. Journal of Accounting Research, 47(5), 1201-1248. http://doi.org/10.1111/j.1475679X.2009.00348.X

Dechow, P. M., Hutton, A. P., \& Sloan, R. G. (2000). The Relation between Analysts' Forecasts of Long-Term Earnings Growth and Stock Price Performance Following Equity Offerings. Contemporary Accounting Research, 17(1), 1-32. http://doi.org/10.1111/j.19113846.2000.tb00908.x

Demirakos, E. G., Strong, N. C., \& Walker, M. (2010). Does Valuation Model Choice Affect Target Price Accuracy? European Accounting Review (Vol. 19). http://doi.org/10.1080/09638180902990630

Farooq, O. (2013). Who was informative? Performance of foreign and local analysts' stock recommendations during the Asian financial crisis. Research in International Business and Finance, 29(1), 61-76. http://doi.org/10.1016/j.ribaf.2013.03.001

Francis, J. (1997). Discussion of Self-Selection and Analyst Coverage. Journal of Accounting Research, 35(3), 201-208. Retrieved from http://search.ebscohost.com/login.aspx?direct=true \&db=bth\&AN=361375\&site=ehostlive \&scope $=$ site

Friesen, G., \& Weller, P. a. (2006). Quantifying cognitive biases in analyst earnings forecasts. Journal of 
Financial Markets, 9(4), 333-365. http://doi.org/10.1016/j.finmar.2006.07.001

Healy, P. M., \& Palepu, K. G. (2001). Information asymmetry, corporate disclosure, and the capital markets: A review of the empirical disclosure literature. Journal of Accounting and Economics, 31(1-3), 405-440. http://doi.org/10.1016/S0165-4101(01)00018-0

Imam, S., Barker, R., \& Clubb, C. (2008). The use of valuation models by UK investment analysts. European Accounting Review, 17(3), 503-535. http://doi.org/10.1080/09638180802016650

Jegadeesh, N., \& Kim, W. (2006). Value of analyst recommendations: International evidence. Journal of Financial Markets, 9(3), 274-309. http://doi.org/10.1016/j.finmar.2006.05.001

Karamanou, I. (2012). Value relevance of analyst earnings forecasts in emerging markets. Advances in Accounting, 28(1), 128-137. http://doi.org/10.1016/j.adiac.2012.03.002

Kliger, D., \& Kudryavtsev, A. (2013). Volatility expectations and the reaction to analyst recommendations. Journal of Economic Psychology, 37, 1-6. http://doi.org/10.1016/j.joep.2013.04.003

Libby, R., \& Lewis, B. L. (1982). Human information processing research in accounting: The state of the art in 1982. Accounting, Organizations and Society, 7(3), 231-285. http://doi.org/10.1016/0361-3682(82)90004-6

Lustgarten, S., \& Tang, C. (2008). Analysts' Heterogeneous Earnings Forecasts and Stock Recommendations. Journal of Accounting, Auditing \& Finance, 23(3), 377-401. http://doi.org/Article

Mest, D. P., \& Plummer, E. (2000). Revisions in analysts' earnings forecasts: evidence of non-linear adaptive expectations. Journal of Forecasting, 19(6), 467-484. http://doi.org/10.1002/1099131X(200011) 19:6<467::AID-FOR760>3.0.CO;2-A

Ramnath, S., Rock, S., \& Shane, P. (2008). The financial analyst forecasting literature: A taxonomy with suggestions for further research. International Journal of Forecasting, 24(1), 34-75. http://doi.org/10.1016/j.ijforecast.2007.12.006

Stickel, S. E. (1990). Predicting Individual Analyst Earnings Forecasts. Journal of Accounting Research, 28(2), 409-417. http://doi.org/10.2307/2491158

Wong, M. H. F., \& Zhang, X. F. (2014). CEO Optimism and Analyst Forecast Bias. Journal of Accounting, Auditing \& Finance, 29(3), 367-392. http://doi.org/10.1177/0148558X14536185

Yin, H., \& Zhang, H. (2014). Tournaments of financial analysts. Review of Accounting Studies, 19(2), 573-605. http://doi.org/10.1007/s11142-013-9255-6 